\title{
Faculty Seminar Series: A Window into Research Potentials and Productivity
}

No academic institution can achieve and sustain international recognition without significant growth in scientific knowledge through research. Important findings from research should be disseminated through local meetings and international conferences and promptly submitted for publication. To foster such dissemination of research, at the beginning of the 1995 academic year the Faculty of Medicine, Health Sciences Centre, Kuwait University, Kuwait, started the Faculty Seminar series, initiated by the Dean, Prof. Abdullatif Al-Bader, and the Vice-Dean, Research, Prof. Olav Thulesius. The ultimate objective was to create a forum for the dissemination of research findings as the basic foundation in the fulfilment of the objectives of innovative teaching, training and medical education, community services and quality medical care to the citizenry. Since its inception, the Faculty Seminar series has been nurtured successively, initially by a committee chaired by Prof. Christopher Ford that included Prof. Phillip Moody, Prof. Raj Raghupathy and Dr. Aida Shihab-Eldeen, and then by Prof. Mustafa Abu Salim, Prof. Abayomi Akanji and Prof. Suhail Ahmad as successive coordinators. It is now a bi-monthly Tuesday event.

During the previous academic year, working in collaboration with Medical Principles and Practice, the international journal of the Kuwait University Health Sciences Centre, it was decided to publish these presentations as a supplement to the journal to be named Faculty Seminars. This inaugural issue will feature six reviews, mostly from the Faculty of Medicine. Future Faculty Seminars will include reviews from the other faculties of the Health Sciences Centre. A brief overview of the presentations featured in the inaugural issue follows.

In 'Long-Lasting Impact of Early Life Immune Stress on Neuroimmune Functions', A. Mouihate [this issue, pp. 3-7] explored the effects of early prenatal stress on the neuroimmune system. Data from a huge body of research suggest that a single immune challenge during a critical window of pregnancy alters the neuroimmune response in adult offspring. Proinflammatory cytokines, which are key mediators in intersystem neuroimmune interactions, represent the common components in different types of prenatal pathology leading to severe neurological and mental disorders. Parental exposure to proinflammatory cytokines is considered a risk factor for the development of nervous and mental pathological conditions such as schizophrenia, attention deficit hyperactivity disorder, autism, and parkinsonism as a result of programming or imprinting.

R. Raghupathy [this issue, pp. 8-19] in 'Cytokines as Key Players in the Pathophysiology of Preeclampsia' discussed the role of cytokines in the pathogenesis of preeclampsia, the most common hypertensive disease of pregnancy. The two-stage model of preeclampsia propos-

\begin{tabular}{ll}
\hline KARGER & $\begin{array}{l}\text { ( ) 2013 S. Karger AG, Basel } \\
1011-7571 / 13 / 0227-0001 \$ 38.00 / 0 \quad \text { Karger }\end{array}$ \\
E-Mail karger@karger.com & $\begin{array}{l}\text { This is an Open Access article licensed under the terms of the } \\
\text { www.karger.com/mpp }\end{array}$ \\
$\begin{array}{l}\text { Creative Commons Attribution-NonCommercial 3.0 Un- } \\
\text { ported license (CC BY-NC) (www.karger.com/OA-license), } \\
\text { applicable to the online version of the article only. Distribu- } \\
\text { tion permitted for non-commercial purposes only. }\end{array}$
\end{tabular}


es that a poorly perfused placenta (stage 1) produces factor(s) leading to the clinical manifestations of preeclampsia (stage 2).

'Community-Acquired Methicillin-Resistant Staphylococcus aureus: The New Face of an Old Foe?', presented by E.E. Udo [this issue, pp. 20-29], described the nature, risk factors and mechanisms of MRSA infections in hospitals or other health care facilities, such as nursing homes and dialysis centres. Some contemporary CA-MRSA clones, specifically the SWP CA-MRSA (ST30-MRSA), have common ancestry to phage 80/81 Staphylococcus aureus (Old Face) that caused epidemic of infection in the 1950s.

A.E. Omu [this issue, pp. 30-42] in 'Sperm Parameters: Paradigmatic Index of Good Health and Longevity' elucidated the effect of medical disorders and social habits on sperm quality and whether or not sperm quality can be used as an index of good health and longevity in men. It shows that altered sperm parameters not only indicate reproductive disorders but may also reflect the general health status.

A.S. Mustafa [this issue, pp. 43-51] presented 'In silico Analysis and Experimental Validation of Mycobacterium tuberculosis-Specific Proteins and Peptides of Mycobacterium tuberculosis for Immunological Diagnosis and Vaccine Development'. He concluded that the bioinformaticsbased in silico identification of promiscuous antigens and peptides of $M$. tuberculosis is a useful approach to identify new candidates important for diagnosis and vaccine applications.

E.O. Kehinde [this issue, pp. 52-61] in 'They See a Rat, We Seek a Cure for Diseases: The Current Status of Ani- mal Experimentation in Medical Practice' justified the use of laboratory animals in research. Considerable progress has been made in research due to the use of a wide array of species, including yeast, nematodes, fruit flies, rodents, and nonhuman primates. The greatest problem with animal research is the 'bitter' and aggressive opposition from animal rights groups.

As an outreach event, the Faculty Seminar series is a tool for collaboration that encourages the development of long-term interdepartmental/interdisciplinary research agendas. For young and newly appointed academic staff, the Faculty Seminar series is a venue for the identification of possible areas of research, assistance and collaboration. Comments by participants may lead to innovations by the research team involved. The publication of these selected seminars as a supplement of Medical Principles and Practice is a milestone, the attainment of further development of the Faculty Seminar series. These presentations have provided a window into the high quality of research that has been carried out and is ongoing at the Faculty of Medicine in particular and the Health Sciences Centre in general.

Prof. Alexander E. Omu Guest Editor

\section{Disclosure Statement}

The author declares that no conflicts of interest exist. 